\title{
GROSS DOMESTIC PRODUCT GROWTH RATE ANALYZING BASED ON PRICE INDEXES, IMPORT AND EXPORT FACTORS
}

Biljana Petkovićl, Boris Kuzman', Miljana Barjaktarević3

*Corresponding authorE-mail: biljana.p85@gmail.com

\begin{abstract}
A R T I C LE IN F O
A B S T R A C T

Original Article

Received: 11 March 2020

Accepted: 23 April 2020

doi:10.5937/ekoPolj2002405P

UDC $31: 33.562 / .564$

Keywords:

economic development, price indexes, urban and rural factors, gross domestic product

JEL: O1, O18

Economic development could be presented by gross domestic product to show how different factors affect the development. Gross domestic product could be affected by different nonlinear factors in positive or negative way. Hence it is suitable to apply artificial intelligence techniques in order to track the gross domestic product variation in depend on the factors. AI techniques require only input and output data pairs in order to catch the output variations based on the input factors. Therefore in this study adaptive neuro fuzzy inference system was applied in order to select the most relevant factors for gross domestic product growth rate. These factors are whole sale price index, consumer price index in urban areas, consumer price index in rural areas, state per capita income, exports, import and industry income. Results shown that the whole sale price index has the highest relevance on the gross domestic product growth rate.
\end{abstract}

(C) 2020 EA. All rights reserved.

\section{Introduction}

Recently artificial techniques became main instrument for modelling and analyzing of complex nonlinear systems. Their application in every area is widely accepted and acknowledged. One of the potential application of artificial techniques is in social problems like economic development (Markovićet.al., 2017; Mladenović et.al., 2016). Economic development could be analyzed based on different indicators but gross domestic product (GDP) is widely accepted and used indicator to track economic

1 Biljana Petkovic, Ph.D student, Alfa BK University - Faculty of Finance, Banking and Auditing, Belgrade, Serbia, Pone +381 0638962059, E-mail: biljana.p85@gmail.com, ORCID ID https://orcid.org/0000-0003-1859-804X

2 Boris Kuzman, Ph.D., Associate Professor, Institute of Agricultural Economics, 15 Volgina Street, SRB-11060 Belgrade, Serbia, Phone: +381 63299 111, E-mail: kuzmanboris@ yahoo.com, ORCID ID https://orcid.org/0000-0002-8661-2993

3 Miljana Barjaktarović, Ph.D., Full Professor, Alfa BK University - Faculty of Finance, Banking and Auditing, 3 Palmira Toljatija Street, SRB-1070 Belgrade, Serbia, Phone: +381 694410620 , E-mail: miljana.barjaktarovic@alfa.edu.rs, ORCID ID (https://orcid.org/0000-0002-3491-9846 ) 
development. There are many investigations of GDP according to different input factors (Todorović et.al., 2018).

In paper (Jovic, 2019) was investigated the effect of exchange rate pass-through (ERPT) into aggregate import prices and afterwards exchange rate effect on gross domestic product (GDP) was investigated by adaptive neuro fuzzy inference system (ANFIS). GDP per capita is one of the most important indicators of social welfare and all countries try to increase their GDP per capita to contribute to their population's happiness and well-being, as well as strengthen their nation's standing in international relations (Tümer, Akkuş, 2018). Expenditures on health care continue to increase substantially, both absolutely and relative to national income, throughout most of the developed world. In study (Mladenovićet.al., 2016) was analyzed the influence of health care expenditures on the economic growth. Aggregate accounting earnings growth is an incrementally significant leading indicator of growth in nominal GDP (Konchitchki, Patatoukas, 2014). Strong evidence of discontinuities around zero in the distribution of actual minus target GDP growth rates was found in paper (Changjianget. al., 2018). The yield curve - specifically the spread between long term and short term interest rates is a valuable forecasting tool. Results presented in paper (Hvozdenska, 2015) confirmed that 10-year and 3-month yield spread has significant predictive power to real GDP growth after financial crisis. The environment that governs the relationships between carbon dioxide (CO2) emissions and GDP changes over time due to variations in economic growth, regulatory policy and technology. The purpose of research (Marjanovićet.al., 2016) was to develop and apply the Extreme Learning Machine (ELM) to predict GDP based on CO2 emissions.

The main goal of the paper is to present application of adaptive neuro inference system (ANFIS) (Jang, 1993) for GDP analyzing based on input factors influence. The main reason of ANFIS application is strong presence of nonlinear phenomena in the economic problem namely GDP growth rate. There are number of social phenomena like GDP where linearity is exceeded in independent variables (Subic et.al., 2007; Kuzman, Prdić, 2018; Prdic, Kuzman, 2019). Economic aspects have different variables and factors which is challenging to analyzing by conventional approaches (Kuzmanet.al., 2018; Kuzman et.al., 2017; Kuzman et.al., 2016; Kuzman, Prodanović, 2017; Nedelcu et.al, 2015). ANFIS methodology shows good capability to catch and track nonlinearity phenomena since there are multiple parallel operations during training of the ANFIS model. ANFIS technique require only input and output data pairs in order to catch the output variations based on the input factors. In this study ANFIS was applied in order to analyze GDP growth rate based on 7 input factors. These factors are whole sale price index, consumer price index in urban areas, consumer price index in rural areas, state per capita income, exports, import and industry income.

\section{Materials and methods}

In order to perform GDP analysing and prediction there is need to collect input and output data pairs for ANFIS training process. Table 1 shows used input factors and 
output as well. The used input are whole sale price index, consumer price index in urban areas, consumer price index in rural areas, state per capita income, exports, import and industry income. The factors are paired with GDP. After the pairing the ANFIS models are training in order to investigate relationships between inputs and output. All of the data are acquired and arranged based on OECD database for European Union.

Table 1. Input and output factors

\begin{tabular}{|c|c|c|c|c|c|c|c|}
\hline $\begin{array}{c}\text { in 1: } \\
\text { Whole } \\
\text { sale } \\
\text { price } \\
\text { index } \\
\end{array}$ & $\begin{array}{c}\text { in 2: } \\
\text { Consumer } \\
\text { price } \\
\text { index - } \\
\text { Urban }\end{array}$ & $\begin{array}{c}\text { in 3: } \\
\text { Consumer } \\
\text { price } \\
\text { index - } \\
\text { Rural } \\
\end{array}$ & $\begin{array}{c}\text { in 4: State } \\
\text { Per } \\
\text { Capita } \\
\text { Income }\end{array}$ & $\begin{array}{c}\text { in 5: } \\
\text { Export }\end{array}$ & $\begin{array}{l}\text { in 6: } \\
\text { Import }\end{array}$ & $\begin{array}{c}\text { in } 7: \\
\text { Industry } \\
\text { income }\end{array}$ & $\begin{array}{c}\text { output: } \\
\text { Gross } \\
\text { Domestic } \\
\text { Product }\end{array}$ \\
\hline 80.02 & 24.12 & 30.12 & 105 & 4153 & 62367 & 50950 & 286566 \\
\hline 85.02 & 25.35 & 34.35 & 133 & 7128 & 85156 & 53550 & 329567 \\
\hline 88.02 & 42.35 & 48.35 & 192 & 9465 & 87077 & 69640 & 368800 \\
\hline 99.02 & 50.35 & 59.35 & 267 & 12814 & 87774 & 81360 & 405707 \\
\hline 105.02 & 64.35 & 73.35 & 338 & 15849 & 95101 & 108520 & 454014 \\
\hline 115.02 & 76.35 & 82.35 & 416 & 24383 & 101937 & 124950 & 488921 \\
\hline 127.02 & 84.35 & 92.35 & 491 & 32517 & 106792 & 127770 & 532374 \\
\hline 137.02 & 97.35 & 104.35 & 548 & 39963 & 107921 & 154930 & 557097 \\
\hline 142.02 & 108.35 & 114.35 & 617 & 24535 & 90122 & 171020 & 606603 \\
\hline 149.02 & 123.35 & 129.35 & 688 & 26660 & 94372 & 182740 & 645436 \\
\hline 154.02 & 135.35 & 142.35 & 744 & 29635 & 103076 & 209900 & 672222 \\
\hline 171.02 & 143.35 & 152.35 & 822 & 36860 & 125864 & 226330 & 694027 \\
\hline 166.37 & 161.35 & 167.35 & 899 & 39198 & 127785 & 229150 & 720810 \\
\hline 178.87 & 170.35 & 176.35 & 967 & 42547 & 128482 & 197910 & 744859 \\
\hline 181.83 & 179.35 & 186.35 & 1022 & 45581 & 135809 & 230670 & 784955 \\
\hline 199.34 & 193.35 & 200.35 & 1074 & 54166 & 142646 & 242230 & 824655 \\
\hline 225.31 & 210.2 & 219.2 & 1151 & 62300 & 147500 & 259640 & 866113 \\
\hline 263.91 & 251.09 & 260.09 & 1350 & 81500 & 209400 & 230930 & 898394 \\
\hline 277.73 & 256.95 & 263.95 & 1269 & 89700 & 224075 & 255065 & 918879 \\
\hline 303.41 & 302.79 & 311.79 & 1373 & 97900 & 238750 & 272645 & 961097 \\
\hline 333.72 & 314.31 & 322.31 & 1376 & 106100 & 253425 & 313385 & 998466 \\
\hline 346.28 & 330.07 & 335.07 & 1827 & 114300 & 268100 & 338030 & 1031660 \\
\hline 381.53 & 357.26 & 366.26 & 2510 & 141800 & 290700 & 342260 & 1063491 \\
\hline 419.16 & 389.75 & 399.75 & 2719 & 181200 & 298900 & 295400 & 1229030 \\
\hline 451.74 & 416.34 & 425.34 & 3141 & 216900 & 385100 & 365800 & 1449271 \\
\hline 493.78 & 455.34 & 459.45 & 3321 & 317303 & 465527 & 486600 & 1703392 \\
\hline 536.16 & 491.68 & 498.19 & 3688 & 412993 & 522638 & 580500 & 2014567 \\
\hline 613.25 & 572.27 & 572.04 & 3966 & 538988 & 535921 & 606500 & 2156190 \\
\hline
\end{tabular}




\begin{tabular}{|c|c|c|c|c|c|c|c|}
\hline $\begin{array}{c}\text { in 1: } \\
\text { Whole } \\
\text { sale } \\
\text { price } \\
\text { index }\end{array}$ & $\begin{array}{c}\text { in 2: } \\
\text { Consumer } \\
\text { price } \\
\text { index }- \\
\text { Urban }\end{array}$ & $\begin{array}{c}\text { in 3: } \\
\text { Consumer } \\
\text { price } \\
\text { index - } \\
\text { Rural }\end{array}$ & $\begin{array}{c}\text { in 4: State } \\
\text { Per } \\
\text { Capita } \\
\text { Income }\end{array}$ & $\begin{array}{c}\text { in 5: } \\
\text { Export }\end{array}$ & $\begin{array}{c}\text { In 6: } \\
\text { Import }\end{array}$ & $\begin{array}{c}\text { industry } \\
\text { income }\end{array}$ & $\begin{array}{c}\text { output: } \\
\text { Gross } \\
\text { Domestic } \\
\text { Product }\end{array}$ \\
\hline 693.75 & 643.91 & 654.55 & 4428 & 688423 & 731065 & 767400 & 2484052 \\
\hline 718.76 & 689.73 & 695.71 & 5237 & 908580 & 811180 & 884600 & 2886822 \\
\hline 779.23 & 751.65 & 766.28 & 6935 & 1246009 & 1254153 & 1156200 & 3522440 \\
\hline 851.31 & 826.35 & 836.67 & 7236 & 1583283 & 1741672 & 1320500 & 4793736 \\
\hline 937.9 & 934.09 & 935.51 & 9954 & 1759627 & 1496654 & 1348700 & 5815175 \\
\hline 1046.06 & 1091.42 & 1093 & 11215 & 1652964 & 3687789 & 1036300 & 6613382 \\
\hline 1162.23 & 1165.5 & 1164.67 & 15152 & 1877128 & 2348290 & 1363900 & 8103589 \\
\hline 1199.27 & 1217.47 & 1227.47 & 17525 & 2698375 & 2560016 & 1479500 & 10525616 \\
\hline 1223.26 & 1270.23 & 1280.23 & 18786 & 1173696 & 1882137 & 1653600 & 11564416 \\
\hline 1251.77 & 1302.34 & 1310.34 & 21229 & 1263124 & 1862805 & 1462200 & 13173056 \\
\hline 1270.32 & 1339.91 & 1345.91 & 20975 & 2503900 & 3569700 & 1510000 & 13091746 \\
\hline 1340.84 & 1308.79 & 1359.95 & 21738 & 3306800 & 4379800 & 1910100 & 13678087 \\
\hline 1341 & 1333.76 & 1365.73 & 23476 & 3478200 & 7874000 & 2156700 & 14965415 \\
\hline 1373 & 1351.12 & 1370.34 & 25965 & 5129800 & 11298300 & 2798100 & 16718287 \\
\hline 1377 & 1358.37 & 1377.41 & 31920 & 6775900 & 15903500 & 3778400 & 20750283 \\
\hline 1451 & 1425.72 & 1443.49 & 37635 & 9176200 & 19016100 & 3934100 & 24626587 \\
\hline 1539 & 1540.25 & 1540.23 & 36915 & 9060300 & 23098700 & 3971400 & 27928746 \\
\hline 1640 & 1661.45 & 1668.45 & 49831 & 11309300 & 28906600 & 5914300 & 29458192 \\
\hline 1687 & 1778.3 & 1772.38 & 51097 & 9176200 & 19016100 & 7199300 & 33921164 \\
\hline 1798 & 2122.67 & 2134.67 & 70219 & 9060300 & 23098700 & 7695600 & 42491835 \\
\hline 2026 & 2368.72 & 2492.13 & 72993 & 11309300 & 28906600 & 9136400 & 54726662 \\
\hline 2204 & 2623.07 & 2770.16 & 84496 & 11309300 & 28906600 & 9576510 & 63902460 \\
\hline
\end{tabular}

Source: Usha and Balamurugan, 1993

ANFIS network has five layers as it shown in Figure 1. The main core of the ANFIS network is fuzzy inference system. Layer 1 receives the inputs and convert them in the fuzzy value by membership functions. In this study bell shaped membership function is used since the function has the highest capability for the regression of the nonlinear data. 
Figure 1. ANFIS layers

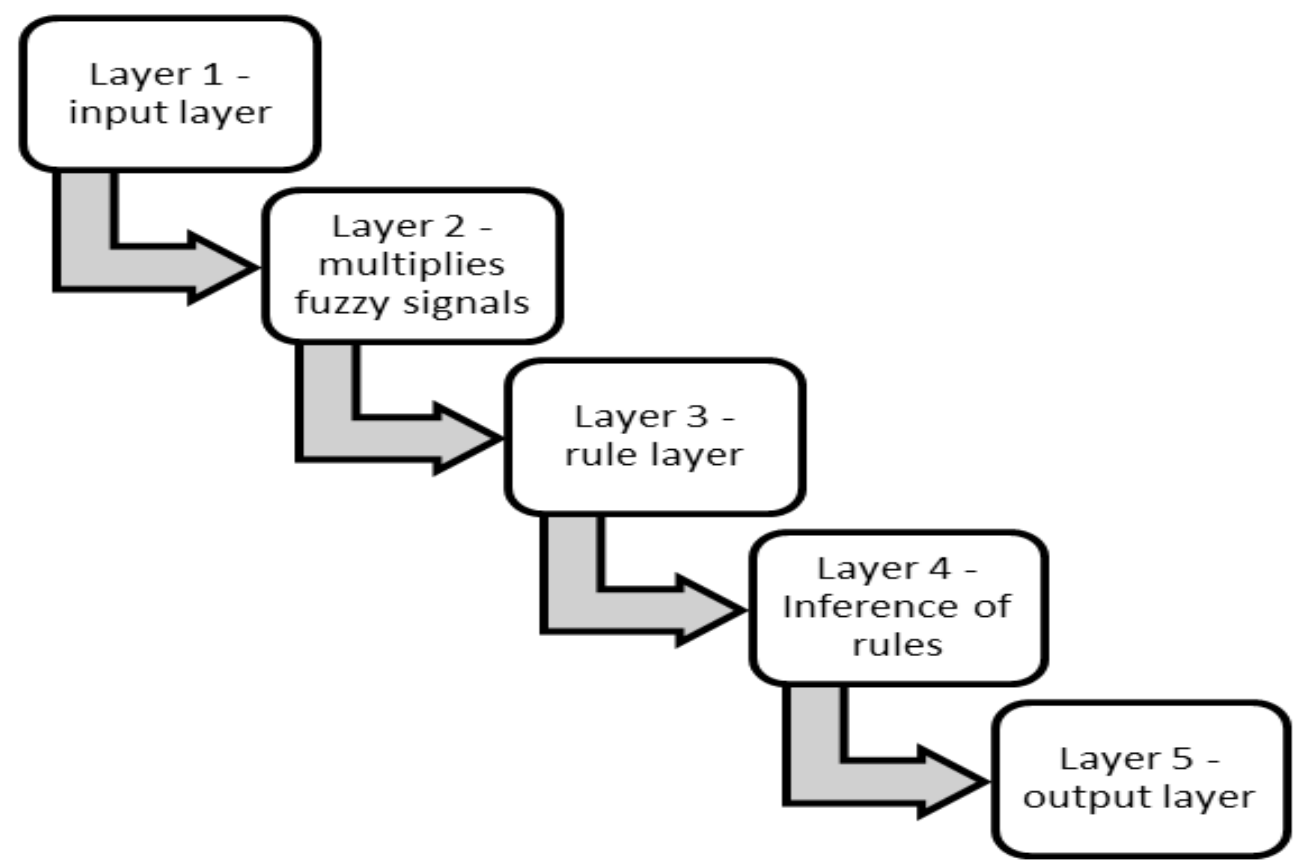

Source: Jang, 1993

Bell-shaped membership functios is defined as follows:

$\mu(x)=\operatorname{bell}\left(x ; a_{i}, b_{i}, c_{i}\right)=\frac{1}{1+\left[\left(\frac{x-c_{i}}{a_{i}}\right)^{2}\right]^{b_{i}}}$

where $\left\{a_{i}, b_{i}, c_{i}\right\}$ is the parameters set and $x$ is input.

Second layer multiplies the fuzzy signals from the first layer and provides the firing strength of as rule. The third layer is the rule layers where all signals from the second layer are normalized. The fourht layer provides the inference of rules and all signals are converted in crisp values. The final layers sumarized the all signals and provied the output crisp value.

Performances of the proposed models are presented as root means square error (RMSE), Coefficient of determination $\left(\mathrm{R}^{2}\right)$ and Pearson coefficient (r) as follows:

1) RMSE

$R M S E=\sqrt{\frac{\sum_{i=1}^{n}\left(P_{i}-O_{i}\right)^{2}}{n}}$, 
2) Pearson correlation coefficient (r)

$$
r=\frac{n\left(\sum_{i=1}^{n} O_{i} \cdot P_{i}\right)-\left(\sum_{i=1}^{n} O_{i}\right) \cdot\left(\sum_{i=1}^{n} P_{i}\right)}{\sqrt{\left(n \sum_{i=1}^{n} O_{i}^{2}-\left(\sum_{i=1}^{n} O_{i}\right)^{2}\right) \cdot\left(n \sum_{i=1}^{n} P_{i}^{2}-\left(\sum_{i=1}^{n} P_{i}\right)^{2}\right)}}
$$

3) Coefficient of determination $\left(R^{2}\right)$

$$
\mathrm{R}^{2}=\frac{\left[\sum_{\mathrm{i}=1}^{\mathrm{n}}\left(\mathrm{O}_{\mathrm{i}}-\overline{\mathrm{O}_{\mathrm{i}}}\right) \cdot\left(\mathrm{P}_{\mathrm{i}}-\overline{\mathrm{P}_{\mathrm{i}}}\right)\right]^{2}}{\sum_{\mathrm{i}=1}^{\mathrm{n}}\left(\mathrm{O}_{\mathrm{i}}-\overline{\mathrm{O}_{\mathrm{i}}}\right) \cdot \sum_{\mathrm{i}=1}^{\mathrm{n}}\left(\mathrm{P}_{\mathrm{i}}-\overline{\mathrm{P}_{\mathrm{i}}}\right)}
$$

where $P_{i}$ and $O_{i}$ are known as the experimental and forecast values, respectively, and $n$ is the total number of dataset.

\section{Results}

GDP growth rate sensitivity is analysed based on factors influence. The influence is estimated according the RMSE values with ANFIS network. Figure 2 shows GDP sensitivity based on 7 input factors. As can be seen the factors with the smallest RMSE after training process has the highest impact on GDP. In other words the GDP is the most sensitive after input 1 (Whole sale price index) variation as can be seen in Figure 2. On the other hand GDP has least sensitivity for input 6 (Import).

Figure 2. Factors influence on GDP

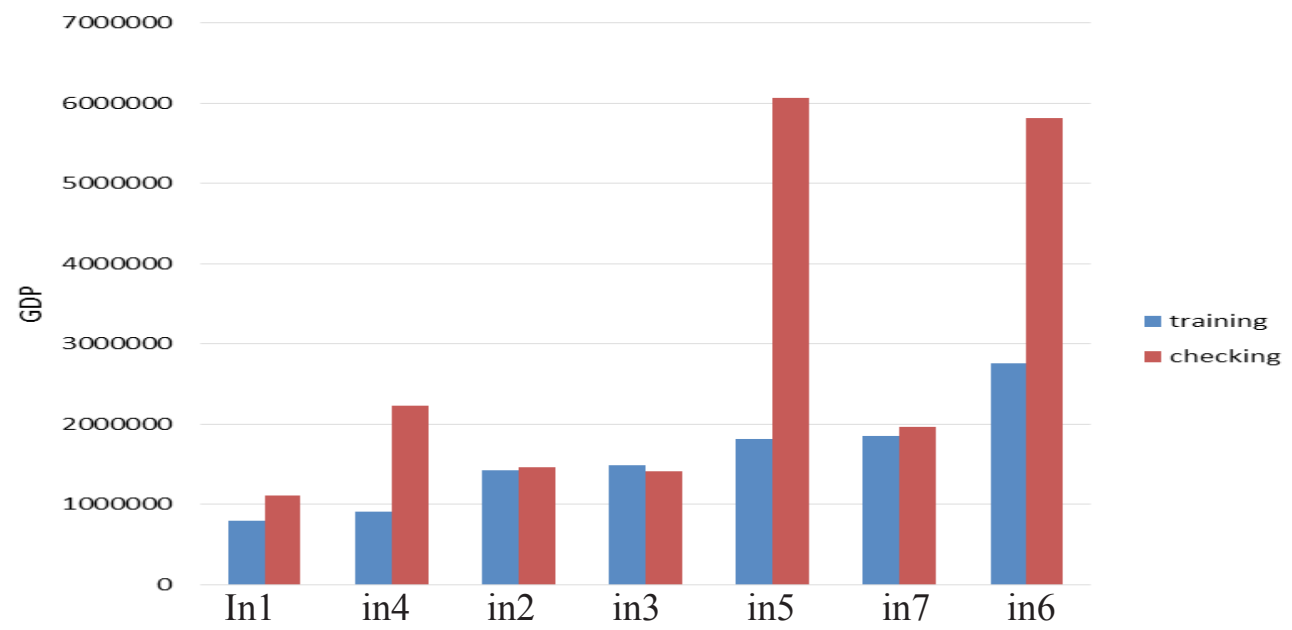

Source: Authors' calculations 
Numerical RMSE values after training and checking of ANFIS network is listed in Table 2 for the single factors influence. Furthermore if one combine two factors in same time corresponding results are presented in Table 3. As can be seen factors 1 and 4 forms the most optimal combination for the GDP.

Table 2. Factors influence on GDP

\begin{tabular}{|l|}
\hline ANFIS model 1: in 1 -->trn=792726.2989, chk $=\mathbf{1 1 1 7 7 5 6 . 7 8 7 4}$ \\
\hline ANFIS model 2: in 2 -->trn=1429807.6034, chk $=1468704.3377$ \\
\hline ANFIS model 3: in3 -->trn=1493654.3340, chk $=1408339.6003$ \\
\hline ANFIS model 4: in4 -->trn=909715.9459, chk $=2230315.8341$ \\
\hline ANFIS model 5: in5 -->trn=1822216.2325, chk $=6067049.2763$ \\
\hline ANFIS model 6: in6 -->trn=2765247.9845, chk $=5810924.3048$ \\
\hline ANFIS model 7: in7 -->trn=1855191.2124, chk $=1967937.0754$ \\
\hline
\end{tabular}

Source: Authors' calculations

Table 3. Two factors influence on GDP

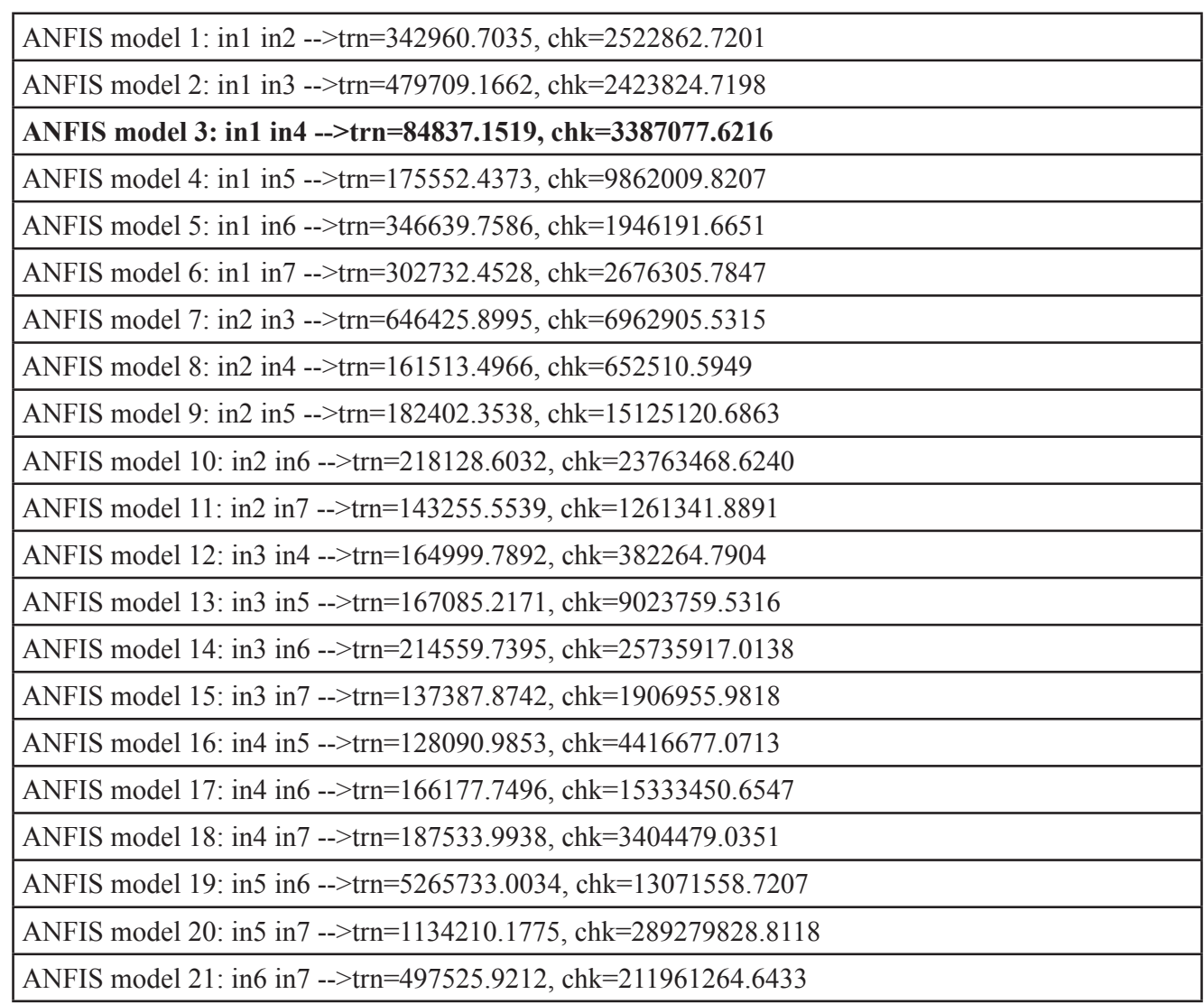

Source: Authors'calculations 
Figure 3 shows scatter plots of GPD prediction by ANFIS based on input 1 while Figure 4 shows scatter plots of GDP prediction by ANFIS based on input 1 and input 4. As can be seen according to the coefficient of determination ANFIS results for two inputs outperforms results for one input. Table 4 shows GDP prediction based on three statistical indicators for ANFIS models. Based on the three indicators one can conclude that the ANFIS with two inputs outperforms ANFIS with one input for the GDP prediction.

Figure 3. ANFIS prediction of GDP based on input 1

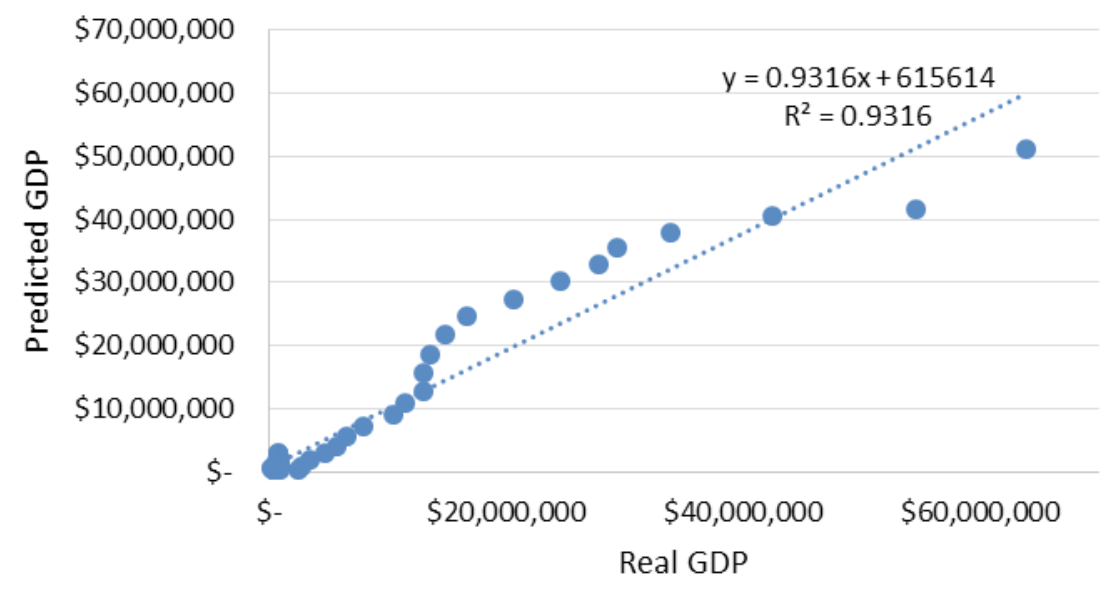

Source: Authors' calculations

Figure 4. ANFIS prediction of GDP based on combination of input 1 and input 4

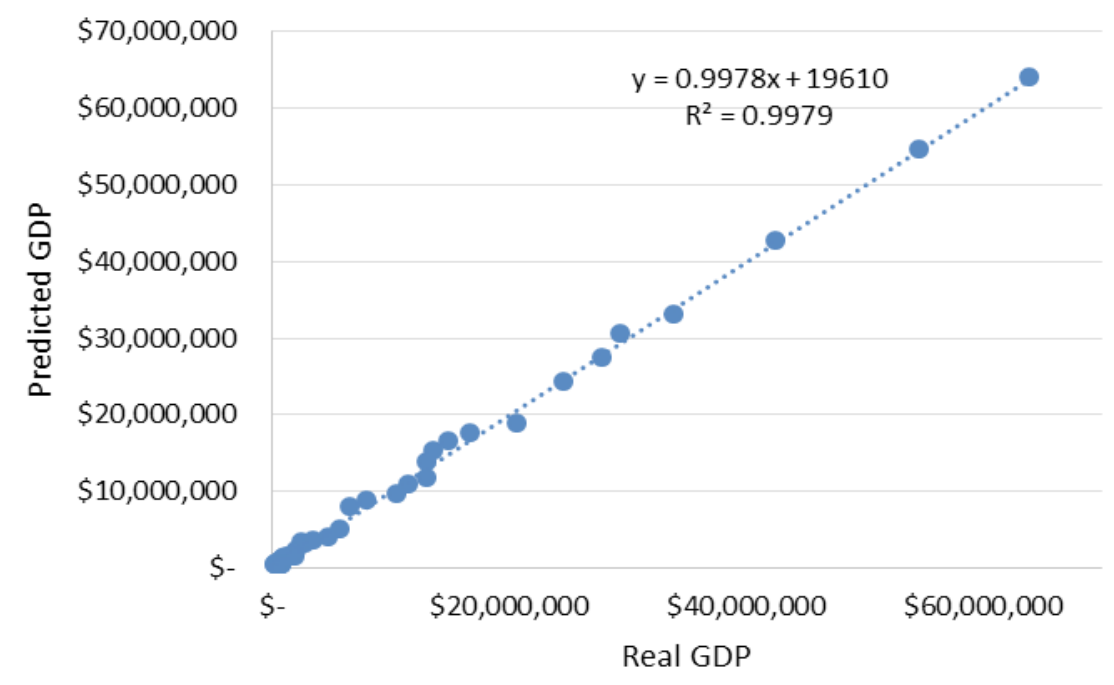

Source: Authors' calculations 
Table 4. Statistical indicators for ANFIS prediction of GDP

\begin{tabular}{|l|l|l|}
\hline & One input (1) & Two inputs (1 and 4) \\
\hline$r$ & 0.9652 & 0.9989 \\
\hline $\mathrm{R}^{2}$ & 0.9316 & 0.9979 \\
\hline RMSE & 3728859.321 & 658353.2683 \\
\hline
\end{tabular}

Source: Authors' calculations

\section{Discussions}

The analysis was performed by artificial intelligence model namely adaptive neuro fuzzy inference system (ANFIS) since there are strong nonlinear relationships between input and output factors in the analyzing.Results shown that the whole sale price index has the highest relevance on the GDP growth rate. Moreover combination of whole sale price index and state per capita income forms the most optimal combination for the GDP. The GDP prediction based on the selected inputs has high accuracy based on three statistical indicators. The main feature of the ANFIS model is easy adaptation to any new inputs.

\section{Conclusions}

The main goal of the paper was to analyze and to make predictive models for gross domestic product (GDP) growth rate based on 7 factors. These factors are whole sale price index, consumer price index in urban areas, consumer price index in rural areas, state per capita income, exports, import and industry income.In conclusion ANFIS could be used effectively for GDP analyzing and prediction based on given factors or any other inputs.

ANFSI network has feature for training based on its performances. Based on this the network parameters are adjusted in order to make the performance optimal. Main goal of the learning type is based on optimization surfaces where there is need to find the optimal conditions for minimum and maximum of the surface.

There are different training laws in the category of learning performance. These learning laws is based on adjusting of network parameters during training process in order to optimize the network performances.

There are two steps during optimization process. The first step is based on definition of the performance criterion. In other words there is need to find a quantity measure for the network performance which is called performance index, which is small when the network produce good results and vice versa. The second step during the optimization process is based on the finding of parameters space in order to wind the performance index.

Optimization of neural networks represent a complex task since it is need to define the performance index of the artificial neural network for the further optimization process. There are several algorithms for optimization of the performance index of artificial neural networks. One of the most popular algorithm is steepest descent algorithm. 
This algorithm require only calculation of function gradient which represent index performance of the network. It is proved that the algorithm will converge up to optimal stationary point if the learning speed is slow. Drawback of the learning algorithm is learning time which is too large. Therefore ANFIS network uses combination of steepest descent algorithm with back propagation in order to increase the learning speed.

ANFIS network has adaptive adjusting feature of the learning parameters with any new additional training. In other words ANFIS network has advantage to save the learned knowledge based on the fuzzy logic system. Once trained ANFIS network has feature to keep the knowledge until new training with new dataset.

\section{Conflict ofinterests}

The authors declare no conflict of interest.

\section{References}

1. Marković, D., Petković, D., Nikolić, V., Milovančević, M., \&Petković, B. (2017). Soft computing prediction of economic growth based in science and technology factors. Physica A: Statistical Mechanics and its Applications, 465, 217-220.

2. Mladenović, I., Milovančević, M., Mladenović, S. S., Marjanović, V., \&Petković, B. (2016). Analyzing and management of health care expenditure and gross domestic product (GDP) growth rate by adaptive neuro-fuzzy technique. Computers in Human Behavior, 64, 524-530.

3. Todorović, J. Đ., Tomić, Z., Denić, N., Petković, D., Kojić, N., Petrović, J., \&Petković, B. (2018). Applicability of Newton's law of cooling in monetary economics. Physica A: Statistical Mechanics and its Applications, 494, 209-217.

4. Jovic, S., Miladinovic, J. S., Micic, R., Markovic, S., \&Rakic, G. (2019). Analysing of exchange rate and gross domestic product (GDP) by adaptive neuro fuzzy inference system (ANFIS). Physica A: Statistical Mechanics and its Applications, 513, 333-338.

5. Tümer, A. E., \&Akkuş, A. (2018). Forecasting gross domestic product per capita using artificial neural networks with non-economical parameters. Physica A: Statistical Mechanics and its Applications, 512, 468-473.

6. Mladenović, I., Milovančević, M., Mladenović, S. S., Marjanović, V., \&Petković, B. (2016). Analyzing and management of health care expenditure and gross domestic product (GDP) growth rate by adaptive neuro-fuzzy technique. Computers in Human Behavior, 64, 524-530.

7. Konchitchki, Y., \&Patatoukas, P. N. (2014). Accounting earnings and gross domestic product. Journal of Accounting and Economics, 57(1), 76-88.

8. Changjiang, L., Wang, K., Zhang, F., \& Xin, Z. (2018). GDP Management to Meet or Beat Growth Targets. Journal of Accounting \& Economics (JAE), Forthcoming.

9. Hvozdenska, J. (2015). The yield curve as a predictor of gross domestic product growth in Nordic countries. Procedia Economics and Finance, 26, 438-445. 
10. Marjanović, V., Milovančević, M., \&Mladenović, I. (2016). Prediction of GDP growth rate based on carbon dioxide (CO2) emissions. Journal of CO2 Utilization, 16, 212-217.

11. Jang, J. S. (1993). ANFIS: adaptive-network-based fuzzy inference system. IEEE transactions on systems, man, and cybernetics, 23(3), 665-685.

12. Subic, J., Cecic, N., \&Kuzman, B. (2007). Economic Aspects of Vegetable Production in Greenhouses-Results of Mini Projects. Economics of Agriculture, 54(297-20163711), 231-240.

13. Kuzman, B., \&Prdić, N. (2018). Strategic significance of wholesale markets in agricultural products sale.

14. Prdic, N., \&Kuzman, B. (2019). The importance of auctions for agroindustrial products trade. Ekonomika, Journal for Economic Theory and Practice and Social Issues, 65(1350-2019-2800), 107-116.

15. Kuzman, B., Ercegovac, D., \&Momčilović, M. (2018). Development of derivative trading on financial market and agribusiness sector in Serbia. Economics of Agriculture, 65(2), 601-616.

16. Kuzman, B., Prdić, N., \&Dobraš, Z. (2017). The importance of the wholesale markets for trade in agricultural products. Economics of Agriculture, 64(3), 1177-1190.

17. Kuzman, B., Stegić, M., \&Subić, J. (2016). Market oriented approach of revealed comparative advantage in international trade. Economics of Agriculture, 63(1), 247-260.

18. Kuzman, B., \&Prodanović, R. (2017). Land Management in Modern Farm Production.

19. Nedelcu, A., Tătaru, A., Subić, J., \&Kuzman, B. (2015). The Local Action Group, Local Sevelopment Model based on Community. Case Study-LGA "Land of Vineyards and Wine" Vrancea. Procedia Economics and Finance, 22, 706-715.

20. Usha, T. M., \& alias Balamurugan, S. A. (2017). Computational modeling of electricity consumption using econometric variables based on neural network training algorithms. Neural Network World, 27(1), 139. 